\title{
The Application of Geomorphology Data Through Landsat Imagery for Drought Detection (Case: Gerokgak Sub-District, Buleleng Regency, Bali)
}

\author{
Wayan Damar Windu Kurniawan ${ }^{1}$, A Sediyo Adi Nugraha ${ }^{1}$, I Gst Ngrh Yoga Jayantara ${ }^{1}$ \\ kurniawan.windu@undiksha.ac.id adi.nugraha@undiksha.ac.id \\ ${ }^{1}$ Universitas Pendidikan Ganesha, Indonesia
}

\begin{abstract}
This research aims at discovering the potential of Landsat imagery for obtaining geomorphological information and its relationship with drought phenomena. The method used for this study is quantitative through the interpretation and examination of aspects of morphometry and morpho-structure-passive interpretation. Concerning the Landsat imaging using composite methods, sharpening and using DEM. The results showed that Landsat 8 imagery was able to provide very detailed information by showing that composite imagery combined with HSV fusion affirmation provides an affirmation of the upper limit of appearance. Moreover, DEM information may contain topographic information and a morpho-passive structure state in the area. This combination is able to provide information on the appearance of landform such as; structural landform, solutional landform, karst landform, volcanic landform, marine landform, and fluvial landform. Based on the results of the interpretation and field surveys, it can be concluded that areas with structural and karst landforms are experiencing faster drought than other areas in the Gerokgak sub-region.
\end{abstract}

Keywords: Geomorfology, Landsat 8, Landform

\section{Introduction}

Geomorphologic information at the surface of the earth can provide various information. The appearance of geomorphology can be obtained through remote sensing image data because it is very useful in recognizing geomorphological features such as minerals, rocks, and shape [1]-[6]. Remote sensing approach to detect and recognize geomorphology using vegetation density level or intensive weathering conditions [6].

The use of remote sensing imagery for geomorphology can use medium and high resolution spatial resolution types. Remote sensing imaging can provide a direct overview of the physical appearance of an area such as soil and geomorphology [7]-[9]. Sabins [9] identified three ways to obtain geomorphological information from remote sensing. The first way is to restore the image when the remote sensing image does not provide clear information about the recording obtained. The second way is by image sharpening, this is necessary when the remote sensing image is less clear and needs to be sharpened with other images that have a higher resolution. Finally, the combination of images is a simple technique to do and the combination will give different colors according to the selected composite. Based on the three ways to recognize the 
aspect of geomorphology almost entirely the form is made as an effort to get the correct information.

Loss of information through remote sensing for geomorphology provides a detailed overview of the extent of a region [10]. The introduction of landscape should make it possible to classify landscape according to the classification of landforms so that they can be easily displayed on a map [9]. Each region has a geomorphological aspect and reflects the conditions that characterize the region, such as drought. Drought is not only influenced by climate change, it is also influenced by its landform (Sudaryatno, 2015). The combination of geomorphology and remote sensing will provide the accuracy of the data for a phenomenon in which it is connected by landscape/landform. Based on that, the purpose of the research conducted wanted to find out how remote sensing data is able to identify geomorphological features and how it relates to drought phenomena.

\section{Study Area and Data}

\subsection{Study Area}

Gerokgak is an area in the north of Bali that belongs to Buleleng Regency. This area is interesting as a research area because topographically has variations as diverse as the northern region is dominated by coastal areas and the southern region is dominated by hills is located on $8^{\circ} 7^{\prime} 17^{\prime}$ ' LS and $114^{\circ} 25^{\prime}$ '53' 'BT. Moreover, land use varies according to shrubs, forests, ponds, rice fields and settlements [11]. Gerokgak region is the area with the largest area in Buleleng Regency so that this will be able to show the linkage of geomorphological relationships with remote sensing data.

\subsection{Remote Sensing Data}

Landsat 8 OLI image is remote sensing data with medium spatial resolution and has various channels (Band 1 - Band 11) that can be used to composite images and image sharpening. Landsat 8 is also available for free on the USGS website and this studies only used one Landsat 8 on 25 August 2020. Not only Landsat 8 imagery, this study uses SRTM (Shuttle Radar Topography Mission) data to obtain information on topographic differences, especially slopes as a basis for distinguishing the appearance of landform seen in one class of landform.

\section{Methodology}

The reduction in geomorphological information through Lansdat imagery is illustrated in Figure 1. The overall process employs an interpretive approach and is supported by field investigation activities.

\subsection{Landsat 8 OLI}

The first step by using Landsat 8 OLI is to use image composites such as composites 567 and 763. Not only Landsat image composite directly uses image sharpening (fusion) by using the HSV technique by using a band with a higher spatial resolution of 15 meters. The difference in color in the two composites has become the first basis to distinguish the appearance of landform in the field of research. 


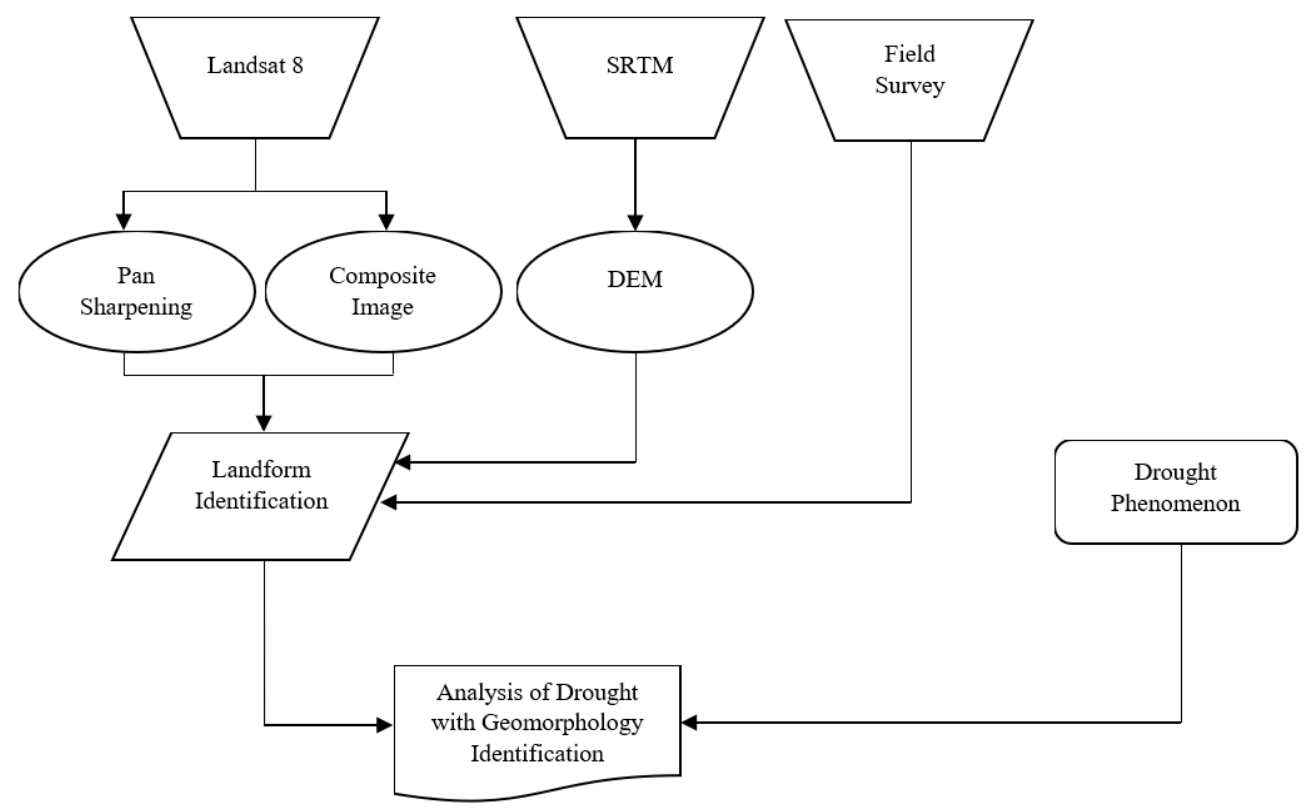

Fig. 1. Research Flowchart

\subsection{SRTM (Shuttle Radar Topography Mission)}

SRTM data processing has an important role in identifying forms. Acquiring information from early SRTM data involves knowing the topographical differences using the hillshade aspect. The appearance of hill shade will provide topographic differences from mountains, hills, and plains more easily recognized. Errors in the treatment of hillshade will provide different information when the results show impolite and vice versa. Next is the identification of slope differences to make it easier to cluster whether it is mountains or hills and this can be tested directly on the ground using Abney level tools.

\section{Result and Discussion}

The processing of Landsat data in the recognition of appearances does not suffice to show the composite color difference. Indeed, composite color explains not only physical characteristics, but also other characteristics such as soil, water and vegetation. The use of composite colors in remote sensing imaging should also include the reflection of spectral patterns possessed by each band in Landsat 8 OLI. Landsat 8 OLI has differences in the type of previous Landsat imagery so the use of composite colors will also differ according to the needs of the information you want to use [12]. Recognizing the appearance of a region uses at least two color composites with different information bases so that the characteristics of information derived from soil, water, and vegetation can be ascertained whether the same or different [13], [14]. Composite 567 has a sensitivity to vegetation information so the appearance of vegetation will look more varied with red color as the main color, while the appearance of the soil will look brighter if there is no vegetation and the appearance of water will be black. In contrast to the 
composite 763 focuses on the appearance of the soil but is placed on the main color of green so that the soil will look green does not mean that there is vegetation. Vegetation will appear darker than blackish green. Whereas the aspect of shallow water with a ground bottom will be different or blue (Figure 2).

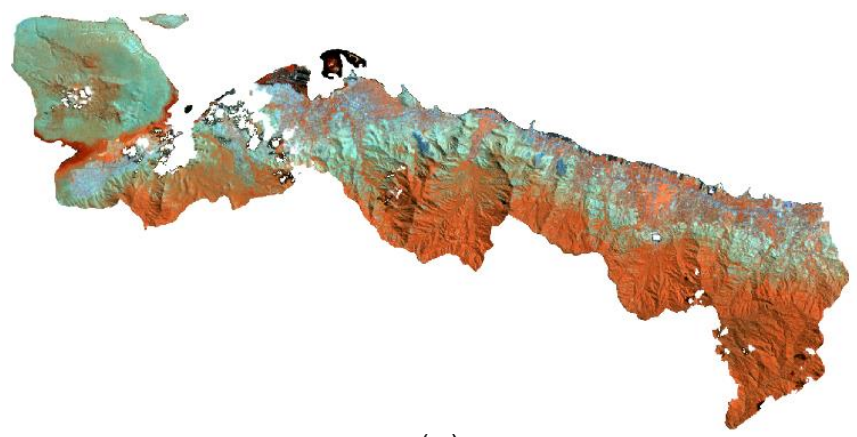

(a)



(b)

Fig. 2. Composite Image (a) 567 and (b) 763

The fusion/sharpening process will provide a better understanding of the boundary differences between vegetation, soil and water in composite imaging. HSV fusion in composite imaging plays a role in asserting limits so that removing limits to distinguish the appearance of landform can be determined. The combination of SRTM data by generating hillshade data and slopes will be easy to recognize differences in the height / topography of the research area [15]. Each topographic difference seen in hillshade have different characteristics even in one type of shape. The difference includes sensitivity to erosion conditions, whether active or non-active. Hills which are still active due to erosion will have steeper tops than hills which will no longer be convex and smooth (Figure 3).

Interpretation of Geomorphology through Landsat image data shows that there are indeed differences in structural areas, especially in the activeness of processes such as erosion. Based on the interpretation of composite imagery and appearance of hill shade shows that the Gerokgak Subdistrict area there are several geomorphological features such as; structural form, solutional form, fluvial form, marine form, and volcanic form (Figure 4). The classification class used as a reference is the result of an interpretation of Suharsono [16] with reference to the scale of 1:50.000. The results of this interpretation have the same results as Novi [17] which identified geomorphology in Buleleng Regency. Field survey activities showed an accuracy rate of $84 \%$ with a high level of similarity in the Gerokgak district. Related to the phenomenon of drought 
that occurs and looking at the condition of the region shows that the central part of Gerokgak tends to be more dry than the northern part of Gerokgak district

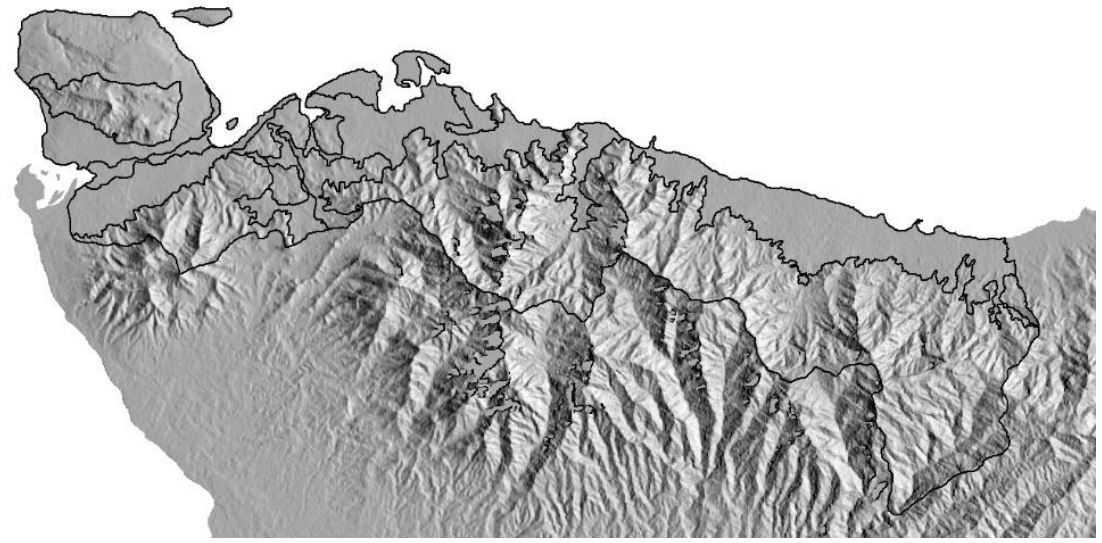

Fig. 3. Hillshade Result

The cause of the middle is drier because the soil formation conditions in the area tend to be slow and difficult so that the growing vegetation is dominated by shrubs. Northern regions with higher topography and with enough temperatures cause soil formation to be faster and able to grow vegetation. Region plains in Gerogak district are dominated by coastal areas and settlements in certain areas. The appearance of land use makes the settlement area look dry even though in some areas it is used as salt cultivation. In addition, in the National Park area where the area is dominated by Karst landform causes some parts of the region there are those that have vegetation to grow and those close to the coast have advantages with mangroves. These regions have the potential for geomorphological drought faster than other regions in Gerokgak Subdistrict, although meteorologically experiencing symptoms of the same rainy season.

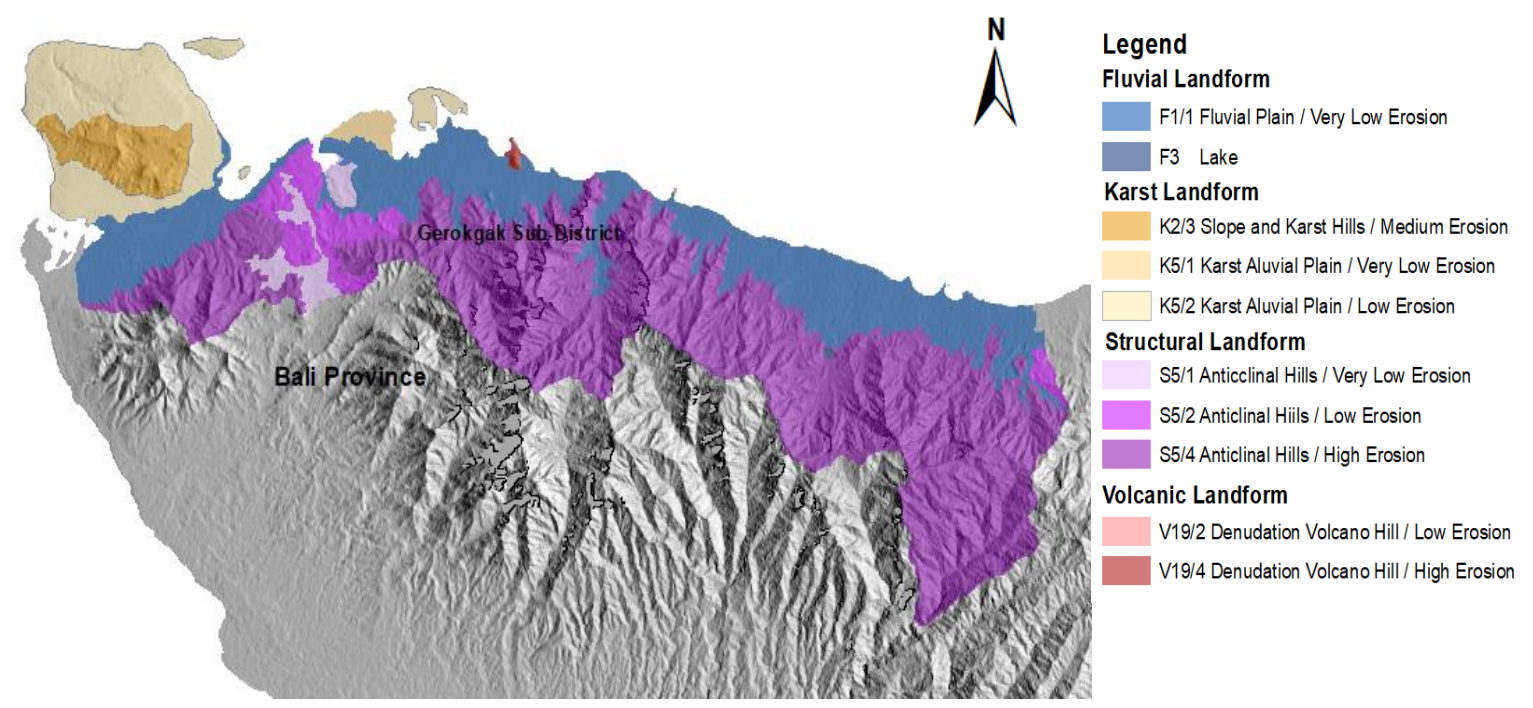

Fig. 4. Geomorphology Gerokgak 


\section{Conclusion}

Geomorphological interpretation with Landsat 8 imagery is usable and provides several features that show the characteristics of the region. Geomorphological appearance of a total of 10 landform, Gerokgak has five landforms even though it is scattered and not dominant. The information obtained from Landsat imagery uses the morphometry and morpho-structurepassive aspects. The appearance of a form that is sensitive to drought conditions is the structural landform and karst landform with slow soil formation and has practiced morpho-passivestructure that rarely occurs. It is expected that the next study will be conducted with a focus on morphonology to complement existing studies and show processes in a region, especially in disaster events.

\section{References}

[1] E. A. Ali, S. O. El Khidir, I. A. A. Babikir, and E. M. Abdelrahman, "Landsat ETM+7 digital image processing techniques for lithological and structural lineament enhancement: Case study around Abidiya Area, Sudan," Open Remote Sens. Journal, vol. 5, pp. 83-89, 2012.

[2] E. E. Mshiu, "Landsat remote sensing data as an alternative approach for geological mapping in Tanzania: A case study in the rung we volcanic province, south-western tanzania," Tanz. J. Sci, vol. 37, pp. 26-36, 2011.

[3] F. F. Sabins, "Remote Sensing for Mineral Exploration," Ore Geol. Rev., vol. 14, pp. 157-183, 1999.

[4] N. Simon, C. A. Ali, K. R. Mohamed, and K. Sharir, "Best Band Ratio Combinations for the Lithological Discrimination of the Dayang Bunting and Tuba Islands, Langkawi, Malaysia, (Gabungan Nisbah Jalur Terbaik untuk Diskriminasi Litologi di Pulau Dayang Bunting dan Pulau Tuba, Langkawi, Malaysia),' Sains Malaysiana, vol. 45, no. 5, pp. 659-667, 2016.

[5] M. A. Manap, M. F. Ramli, W. N. A. Sulaiman, and N. Surip, “, Application of Remote Sensing in the Identification of the Geological Terrain Features in Cameron Highlands, Malysia," Sains Malaysiana, pp. 1-11, 2010.

[6] Franto and D. Oktaviandi, "Kombanisasi Saluran Terbaik Citra Landsat 8 Untuk Penarikan Batas Satuan Batuan di Desa Lubuk dan Sekitarnya, Kabupaten Bangka Tengah," in Prosiding Seminar Nasional Penelitian \& Pengabdian pada Masyarakat, 2018, pp. $155-159$.

[7] B. O. Bauer, "Geomorphology," in Encyclopedia of Geomorphology, First Edit., A. S. Goudie, Ed. 2004, pp. 428-438.

[8] M. J. Smith and C. F. Pain, "Applications of Remote Sensing in Geomorphology," Prog. Phys. Geogr., vol. 33, no. 4, pp. 568-582, 2009.

[9] F. F. Sabins, Remote Sensing: Principles and Application, Third Edition. United States of America: Waveland Press, Inc, 2007.

[10] I. A. Prabowo and D. Isnawan, "Identifikasi Bentuk Lahan Berdasarkan Data Citra Penginderaan Jauh : Studi Kasus di Dome Kulonprogo," in Rekayasa Teknologi Industri dan Informasi 2017 Sekolah Tinggi Teknologi Nasional Yogyakarta, 2017, pp. 313321.

[11] BPS Kabupaten Buleleng, "Badan Pusat Statistik Kabupaten Buleleng," 2021. https://bulelengkab.bps.go.id/statictable/2015/09/21/23/letak-geografis-kabupatenbuleleng.html (accessed Aug. 18, 2021). 
[12] Department of the Interior U.S. Geological Survey, "Landsat 8 Data Users Handbook," 2016. [Online]. Available: https://landsat.usgs.gov/documents/Landsat8DataUsersHandbook.pdf.

[13] K. Pareta and U. Pareta, "Geomorphological Interpretation Through Satellite Imageri \& DEM Data," Am. J. Geophys. Geochemistry Geosystems, vol. 1, no. 2, pp. 19-36, 2015.

[14] S. A. Aliyan, A. S. Bahri, A. Widodo, and W. Utama, "Remote Sensing Data Integration of Landsat 8 and SRTM for Geomorphological Characteristics Identification in Karst Pringkuku, Pacitan, East Java," Int. J. Adv. Sci. Eng. Inf. Technol., vol. 9, no. 1, pp. 212-218, 2019.

[15] G. P. B. Garcia and C. H. Grohmann, "DEM-based Geomorphological Mapping and Landforms Characterization of a Tropical Karst Environment in Southeastern Brazil," South Am. Earth Sci., vol. 93, pp. 14-22, 2019.

[16] P. Suharsono, "Identifikasi Bentuklahan dan Interpretasi Citra untuk Geomorfologi (Kumpulan Bahan Kuliah),” Yogyakarta, 1988.

[17] D. Wahyuni, I. Sukarsa, and A. S. Nugraha, "The Role of Geomorphological Maps in Regional Planning and Management in Indonesia (Case: Buleleng Regency, Bali)," 2021, doi: 10.4108/eai.10-11-2020.2303362. 